\title{
CHICKPEA LANDRACES FROM CENTERS OF THE CROP ORIGIN: DIVERSITY AND DIFFERENCES
}

\section{M.A. VISHNYAKOVA ${ }^{1}$, M.O. BURLYAEVA ${ }^{1}$, S.V. BULYNTSEV ${ }^{2}$, I.V. SEFEROVA ${ }^{1}$, E.S. PLEKHANOVA ${ }^{3}$, S.V. NUZHDIN ${ }^{4}$}

${ }^{1}$ Federal Research Center the N.I. Vavilov All-Russian Institute of Plant Genetic Resources, Federal Agency of Scientific Organizations, 42-44, ul. Bol'shaya Morskaya, St. Petersburg, 190000 Russia, e-mail m.vishnyakova.vir@gmail.com (corresponding author);

2 Kuban Experiment Breeding Station, Branch of Federal Research Center the N.I. Vavilov All-Russian Institute of Plant Genetic Resources, Federal Agency of Scientific Organizations, 2, ul. Tsentral'naya, pos. Botanika, Gul'kevichskii Region, Krasnodarskii krai, 352183 Russia, e-mail s_bulynsev@mail.ru;

${ }^{3}$ Peter the Great St. Petersburg Polytechnic University, 29, ul. Politechnicheskaya, St. Petersburg, 195251 Russia, email plekhanova-elena@ya.ru;

${ }^{4}$ Molecular and Computation Biology, Dornsife College of Letters, Arts and Sciences, University of Southern California, Los Angeles, CA 90089, USA, e-mail: snuzhdin@usc.edu ORCID:

Vishnyakova M.A. orcid.org/0000-0003-2808-7745

Burlyaeva M.O. orcid.org/0000-0002-3708-2594

Bulyntsev S.V. orcid.org/0000-0001-6045-4504

Seferova I.V. orcid.org/0000-0003-3308-9198

Plekhanova E.A. orcid.org/0000-0002-5727-9175

The authors declare no conflict of interests

Nuzhdin S.V. orcid.org/0000-0002-9963-151X

Supported by Russian Science Foundation (project № 16-16-00007)

Received June 11, 2017

\section{Abstract}

Chickpea (Cicer arietinum L.), a grain legume crop, is considered innovative for the Russian Federation. Over the past fifteen years, its area in our country have increased 20 times and reached 420,300 hectares in 2015. The growing demand of chickpea determines the necessity of breeding new varieties. One of the ways to improve the crop could be the introgression of genes from old landraces, especially those from the regions of species genetic diversity, the centers of its origin (i.e. the primary in Turkey and the secondary in Ethiopia). In this paper the question is raised about the diversity and phenotypic differences of the chickpea gene pool growing in the centers of origin about a century ago and preserved in VIR collection. Here, we first showed the differences in the phenotypic characteristics of the oldest chickpeas from two centers of origin. Fifteen morphological, phenological and agronomic features were studied in 75 local varieties from Turkey and 24 ones from Ethiopia. Both in Turkish and in Ethiopian samples, the most variable signs were the number of seeds per plant ( $C v 62.6$ and $70.4 \%$, respectively) and the number of beans per plant ( $C v 62.2$ and $63.0 \%)$. Principal component analysis showed that the first five factors determined $78.9 \%$ of the total variability of traits. Factor $2(22.0 \%$ of the variance) can be called a factor of potential seed production. Correlation analysis revealed a much stronger relationships between all the traits studied in the Ethiopian samples. The correlation between seed production and vegetation period were the strongest $(r \geq 0.9)$. We have revealed association of certain traits of chickpea plants with the geographical zones of the sample origins. Landraces from Ethiopia are fairly homogeneous and have small, dark and angular seeds, low attachment of the first bean and low seed productivity, are more early maturated compared with the Turkish ones. Turkish landraces are characterized by a great variety of all the traits studied, revealing all their grades described in the chickpea descriptors. In this region, the landraces typical of the western Mediterranean, as well as for territories bordering Turkey in the east had been grown. The structure of the variability and the strength of the relations of the traits differed in the landraces from the primary and secondary centers. It is obvious that in plants growing in different ecological and geographical environment, there is a specific communications between the traits, reflecting the presence of different blocks of co-adapted genes or another integrated gene complexes that determine adaptation to a particular environment. Useful characters for breeding are found in landraces from both centers of origin and chickpea diversity.

Keywords: chickpeas (Cicer arietinum L.), centers of origin, phenotypes, variability, factor analysis, structure of traits relationships, diversity, characters for breeding

Chickpea (Cicer arietinum L.) is a grain legume crop that is considered innovative for the Russian Federation. It is very popular in Asian countries (In- 
dia, Pakistan, Syria, Turkey, etc.) and North Africa, and is the second in the world in sowing areas and the third in production among grain legumes (excluding soybeans) [1]. The nutritional value of chickpea is determined by the high content of protein in its seeds (17-30\%) and various macro- and micronutrients [2], which determine a healthy diet. The undoubted agronomic merit of this crop is its high drought resistance. However, in our country, chickpeas, which are also known as mutton or turkey peas, are not well known to consumers. For many years in the Russian Federation, the planted areas of chickpea did not exceed 20-25 thousand hectares. However, nowadays its production has sharply increased, and in 2015 the sowing areas reached 420,300 hectares [3]. This is explained by the fact that chickpea is a highly demanded export crop, although, according to experts, it should take a worthy place in the domestic market.

Given the growing demand for this crop, new highly adaptive varieties are required, in particular, those with improved drought resistance and resistance to diseases, especially resistant to Ascochyta pisi L. Also, precocity is a trait that is relevant for many regions of chickpea production.

Selection significantly narrowed the historical diversity of cultivated chickpeas [4]. To expand the genetic basis of modern varieties, it is necessary to employ diversified donor parents. The VIR collection preserves populations and old local varieties from the centers of chickpea origin with maximum genetic diversity concentrat. Local varieties are a rich gene pool for the search for highly adaptive genotypes $[5,6]$. To date, such varieties in the places of their historical origin are mostly hopelessly lost, as having been almost completely extincted because of replacement by modern commercial varieties, and because of natural disasters, urban, technogenic and other factors that are rapidly changing the modern world.

Introgression of genetic material from local varieties into modern commercial varieties using marker-assisted selection (MAS) can be a radical way to improve them. Therefore, the study of the diversity of local varieties from the centers of origin for a number of selectively significant traits, the identification of the limits of their variability and the search for candidate genes determining variability are relevant for understanding the selection dynamics in the historical perspective and elucidation of its mechanisms.

The center of origin, as well as the place where chickpea was first domesticated, is southeastern Turkey and the adjacent areas of Syria and Iran [7, 8]. N.I. Vavilov [9] considered South-West Asia and the Mediterranean to be the primary center of origin of chickpeas, and Ethiopia was the secondary center. He distinguished four centers of chickpea variety: in the Mediterranean, Central Asia, the Middle East and India [10]. The primary centers of cultivated plant origin, according to N.I. Vavilov, were the ancient centers of civilization, where the primary cultivation of plants took place, and the secondary centers were the territories associated with subsequent periods of the farming culture [9].

We do not know special studies devoted to the differences between the chickpea plants from the primary and secondary centers of origin. In part, these differences are shown by us when studying the phenotypic diversity of local chickpea cultivars from the centers of origin of this crop [11]. In the present article, we first detailed the phenotypic diversity of old local chickpeas from the primary center of origin in Turkey and the secondary one in Ethiopia (Abyssinia) preserved in the collection of N.I. Vavilov All-Russian Institute of Plant Genetic Resources (VIR), for a number of morphological, phonological and agronomical traits and their relationship in both centers.

The aim of the work was to compare manifestations of economically significant traits of chickpea accessions from different centers of origin in the eco- 
logical conditions of Syria close to those in the primary and secondary centers of origin of the crop.

Techniques. Old local chickpeas from the VIR collection, including 75 samples from Turkey and 24 samples from Ethiopia (Abyssinia), were studied for 15 morphological, phenological and agronomic traits in the field in 2002-2005 at the International Center for Agricultural Research in the Dry Areas (ICARDA) in Syria. The Turkish samples are expeditionary collections of P.M. Zhukovsky in 1927. The Ethiopian samples were collected by N.I. Vavilov in 1927, as well as by subsequent VIR expeditions in 1962 and 1970. The sowing in Syria was carried out in February, harvesting in August. The samples were sown randomly in 2-fold replication. The row spacing was $60-70 \mathrm{~cm}$; the distance between the plants was $10 \mathrm{~cm}$. Six plants were analyzed in each replication.

Field assessment was conducted in accordance with the international Descriptors for Chickpea (Cicer arietinum L.) [12] and the ICRISAT descriptor (International Crops Research Institute for the Semi-Arid Tropics) [13].

Calculations were performed using Statistica 7.0 software (StatSoft, Inc., USA) [14]. Pearson's correlation coefficients were calculated as per common methods $[15,16]$. Correlations were considered low at $r<0.5$, average at $0.7>r>0.5$, high at $0.9>r>0.7$, and very strong at $r>0.9$. Correlation pleiades were clustered as described [17]. The variability in the structure of the relationships between traits was assessed using factor analysis. The factor loads were determined by the principal component method. Additionally, the fraction of variance explained by a factor in the total variance and the cumulative fraction of the recoverable factors were calculated. The identification of traits that differentiate the samples by origin was carried out using discriminant analysis [14].

1. Designations of traits studied in chickpeas (Cicer arietinum L.) from the collection of the All-Russian Institute of Plant Genetic Resources (VIR) (Syria, 2002-2005)

\begin{tabular}{l|l}
\hline \multicolumn{1}{c|}{ Trait } & $\begin{array}{l}\text { Designa- } \\
\text { tions }\end{array}$ \\
\hline Biomass yield (plant dry weight with seeds and roots), g & byld \\
Canopy area width per plant, cm & caw \\
Duration of sprouting-flowering period, days & dmat \\
Duration of seedling-maturation period, days & fdu \\
Flowering duration, days & fgc \\
Flower color, points & grh \\
Growth habit (prostrate, spreading, erect), points & hi \\
Harvest index, \% & hlp \\
Height of the lower (first) pod attachment, cm & ppp \\
Pods per plant, pcs. & ptht \\
Plant height, cm & spp \\
Seed per plant, pcs. & styld \\
Straw yield (plant dry weight without seeds), g & styp \\
Seed type, scores & syld \\
Seed yield per plant, g &
\end{tabular}

Results. The region in which samples were studied for a number of traits (Table 1) is located in comparative proximity to the centers of chickpea origin. One of the main differentiation traits of the chickpea gene pool is the type of seeds (desi and kabuli). Desi seeds are small, angular and have a colored seed coat (color from cream to black). Kabuli seeds are large, roundish, and light-colored. The analysis of mean values and variation of traits $(C v)$ in the Ethiopian samples showed narrower variability limits for most of the

traits studied as compared to the Turkish forms (Table 2). The most varying traits in both groups were the number of seeds per plant ( $C v$ was $62.6 \%$ for the Turkish samples and $70.4 \%$ for the Abyssinian samples) and the number of pods per plant ( $C v$ was $62.2 \%$ for the Turkish samples and $63.0 \%$ for the Ethiopian samples). However, traits such as seed color and type, the duration of the sprouting-flowering and seedling-maturing periods, were less variable in the Ethiopian native varieties.

The Ethiopian samples, except of one, had seeds of desi red, brown and black type, whereas in most of the Turkish samples $(57 \%)$ the type of seeds was 
classified as kabuli. In the Turkish gene pool, light seeds were found to be characteristic of about half of the samples, fractions with pink and brown seed hulls made up $15 \%$ of the total number; the rest showed all the other seed colors as per the chickpea descriptors except black.

Factor analysis revealed the structure of the relationship between the traits studied in the Turkish and Ethiopian samples (Table 3). The first five factors determined $78.9 \%$ of the total trait variability. Factor 1 (F1 - 30.0\% dispersion) revealed a positive relationship between the dry biomass of plants (with seeds and roots) and straw yield, plant height and lower attachment of the lower pod, color of the flower and type of seed, and a negative relationship with the harvest index. This factor can be interpreted as a characteristic of a plant's ability to gain and accumulate biomass.

2. Descriptive statistics of the studied samples of chickpeas (Cicer arietinum L.) of different origin from the VIR collection (N.I. Vavilov All-Russian Institute of Plant Genetic Resources) (Syria, 2002-2005)

\begin{tabular}{|c|c|c|c|c|c|c|c|c|c|c|}
\hline \multirow[t]{2}{*}{ Trait } & \multicolumn{2}{|c|}{ Mean } & \multicolumn{2}{|c|}{ Min } & \multicolumn{2}{|r|}{ Max } & \multicolumn{2}{|c|}{$\begin{array}{l}\text { Standard } \\
\text { Deviation }\end{array}$} & \multicolumn{2}{|c|}{$C v, \%$} \\
\hline & Turkey & Ethiopia & Turkey & Ethiopia & Turkey & Ethiopia & Turkey & Ethiopia & Turkey & Ethiopia \\
\hline byld & 53.8 & 39.4 & 19.8 & 18.1 & 114.6 & 70.0 & 15.6 & 10.4 & 29.0 & 21.9 \\
\hline caw & 63.5 & 55.0 & 43.5 & 39.0 & 91.0 & 72.0 & 8.7 & 7.7 & 15.6 & 11.0 \\
\hline dflr & 106.4 & 107.9 & 96.5 & 100.0 & 140.0 & 119.0 & 9.7 & 6.1 & 13.6 & 13.7 \\
\hline dmat & 164.1 & 157.3 & 129.0 & 149.0 & 183.0 & 171.0 & 8.6 & 5.2 & 5.3 & 2.6 \\
\hline fdu & 25.9 & 27.8 & 9.0 & 18.0 & 34.0 & 31.0 & 4.0 & 3.1 & 9.1 & 5.9 \\
\hline fgc & 5.3 & 4.1 & 1.0 & 4.0 & 6.5 & 6.0 & 1.1 & 0.4 & 20.1 & 11.3 \\
\hline grh & 2.7 & 2.5 & 1.0 & 2.0 & 4.0 & 3.0 & 0.5 & 0.5 & 19.3 & 20.5 \\
\hline hi & 40.9 & 45.9 & 26.0 & 24.3 & 72.1 & 59.6 & 6.8 & 8.7 & 16.6 & 19.4 \\
\hline hlp & 28.8 & 21.0 & 20.0 & 13.0 & 41.0 & 30.0 & 3.8 & 4.9 & 13.1 & 23.1 \\
\hline ppp & 33.3 & 61.1 & 12.7 & 18.3 & 142.0 & 147.0 & 20.7 & 40.6 & 62.2 & 63.0 \\
\hline ptht & 54.2 & 46.6 & 38.0 & 39.0 & 70.0 & 53.0 & 6.9 & 5.0 & 12.7 & 10.3 \\
\hline spp & 34.1 & 76.6 & 13.0 & 18.0 & 145.0 & 196.0 & 21.3 & 57.1 & 62.6 & 70.4 \\
\hline styld & 33.5 & 19.8 & 5.5 & 6.2 & 65.2 & 32.3 & 10.7 & 6.4 & 31.9 & 27.1 \\
\hline styp & 1.6 & 1.0 & 1.0 & 1.0 & 2.0 & 2.0 & 0.5 & 0.2 & 31.6 & 20.4 \\
\hline syld & 20.9 & 16.8 & 11.4 & 5.1 & 52.1 & 25.8 & 7.0 & 5.4 & 33.5 & 28.6 \\
\hline
\end{tabular}

3. Factor loads of $\mathbf{1 5}$ traits for 99 Turkish and Ethiopian chickpeas from the VIR collection (N.I. Vavilov All-Russian Institute of Plant Genetic Resources) (Syria, 2002-2005)

\begin{tabular}{|c|c|c|c|c|c|}
\hline \multirow{2}{*}{ Trait } & \multicolumn{5}{|c|}{ Factor } \\
\hline & 1 & 2 & 3 & 4 & 5 \\
\hline Duration of flowering, days & -0.20 & -0.24 & -0.18 & 0.77 & 0.30 \\
\hline Time to $50 \%$ flowering, days & -0.05 & -0.73 & 0.29 & -0.42 & 0.02 \\
\hline Canopy width, $\mathrm{cm}$ & 0.52 & -0.03 & -0.11 & 0.37 & 0.21 \\
\hline Height of the lower (first) pod attachment, $\mathrm{cm}$ & 0.76 & 0.01 & -0.29 & -0.40 & 0.17 \\
\hline Plant height, $\mathrm{cm}$ & 0.67 & -0.31 & -0.27 & -0.20 & 0.37 \\
\hline Growth habit, point & 0.11 & -0.26 & -0.02 & 0.22 & -0.77 \\
\hline Color of flowers, points & 0.66 & 0.20 & 0.57 & 0.13 & -0.06 \\
\hline Type of seeds, points & 0.64 & 0.18 & 0.66 & 0.17 & -0.06 \\
\hline Time before flowering, days & 0.47 & -0.36 & 0.55 & -0.06 & 0.21 \\
\hline Pods per plant, pcs. & -0.45 & -0.78 & 0.16 & 0.12 & 0.17 \\
\hline Plant dry weight with seeds and roots, $\mathrm{g}$ & 0.69 & -0.55 & -0.24 & 0.08 & -0.20 \\
\hline Seeds per plant, $\mathrm{g}$ & 0.32 & -0.77 & -0.21 & -0.03 & -0.20 \\
\hline Straw yield, kg/ha & 0.81 & -0.32 & -0.19 & 0.19 & -0.11 \\
\hline Harvest index, \% & -0.56 & -0.40 & 0.07 & -0.19 & -0.18 \\
\hline Seeds per plant, pcs. & -0.53 & -0.72 & 0.21 & 0.13 & 0.18 \\
\hline Fraction of total dispersion, $\%$ & 30.00 & 22.00 & 10.40 & 8.80 & 7.50 \\
\hline Cumulative dispersion, $\%$ & 30.00 & 52.00 & 62.40 & 71.40 & 78.90 \\
\hline
\end{tabular}

Factor 2 (F2 - $22.0 \%$ of the variance) can be called a factor of potential seed production. It shows a consistent change in pods per plant, the dry weight of a plant with seeds, the seed number and weight per plant, and the duration of the shooting-flowering period. Factor 3 (F3 - $10.4 \%$ dispersion) grouped flower color, sprouting-ripening period, and seed type. It can be condi- 
tionally called a factor that reveals the differentiation of samples according to the type of seeds (desi, kabuli). Factor 4 (F4 - 8.8\% of dispersion) combined the flowering period with the shooting-flowering period and the height of attachment of the lower pod with a negative relationship of these traits. In factor 5 (F5 $7.5 \%$ dispersion), the growth habit (erect or compact plants) and the height (length) of the plant were negatively associated (that is, for compact plant habitus the length of the main shoot is less than that for spreading or prostrate ones).

Figure 1 shows the location of the samples in the space of the first two factors. The samples from Turkey were distributed for the most part of the diagram area, since they are characterized by various combinations of traits. The samples from Ethiopia, except one, were concentrated in the left upper part and in the middle zones. Obviously, the Ethiopian local varieties are much less diverse.

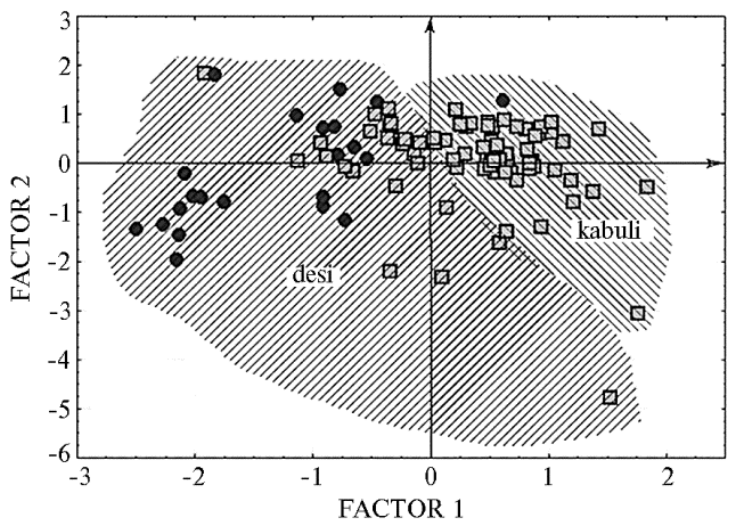

Fig. 1. Distribution of Turkish (•) and Ethiopic ( $\square$ ) chickpea samples from the VIR collection (N.I. Vavilov All-Russian Institute of Plant Genetic Resources) in the space of the first two factors: desi and kabuli are the types of seeds (Syria, 2002- 2005).

A step-by-step discriminant analysis was performed to identify characteristics that divide local varieties into groups of origin. As a result, four most significant traits were identified: spp (seeds per plant), hlp (the height of the lower pod attachment), syld

(seed yield per pant) and grh (growth habit). The distribution of the samples in the space of the canonical axes is shown in the graph (Fig. 2). The arrangement of the samples turned out to be similar to their distribution in the factor space. In the left part of the graph there are early maturing unproductive samples with dark seeds, a larger seed number per plant and a low attachment height of the first pod (predominantly Ethiopian forms), in the right part there are late maturing, productive plants with light seeds, a comparatively low number of seeds per plant and high attachment of the lower pod (mostly Turkish forms).

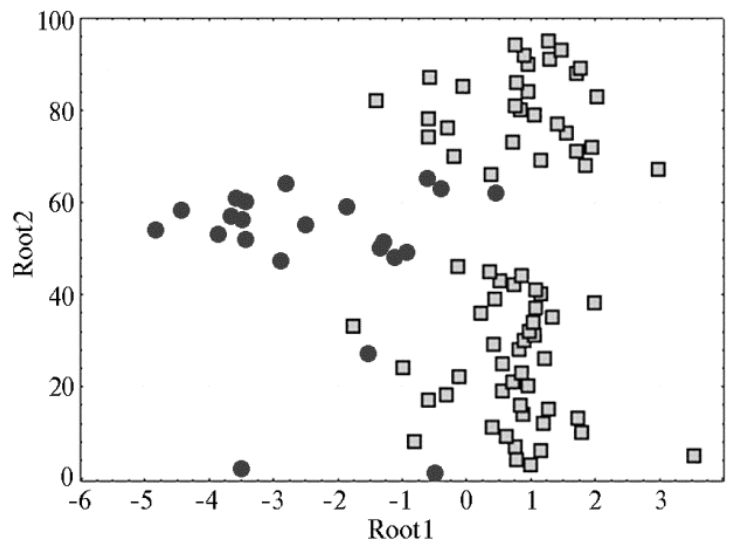

Fig. 2. The distribution of Turkish (•) and Ethiopic ( $\square$ ) chickpea samples from the VIR collection (N.I. Vavilov AllRussian Institute of Plant Genetic Resources) in the space of the first two factors: in the space of the canonical axes Root1 and Root2 (Syria, 2002-2005).

To expand our understanding of the variability of the relationship between the chickpea traits, correlative pleiades were constructed separately for each of the groups (24 Ethiopian and 75 Turkish samples). In addition, for a more accurate and reliable comparison of the correlation structure in different samples from 75 Turkish samples, a set of 24 samples was randomly selected. Analysis of correlation pleiades revealed a much stronger conjugation between all the investigated 

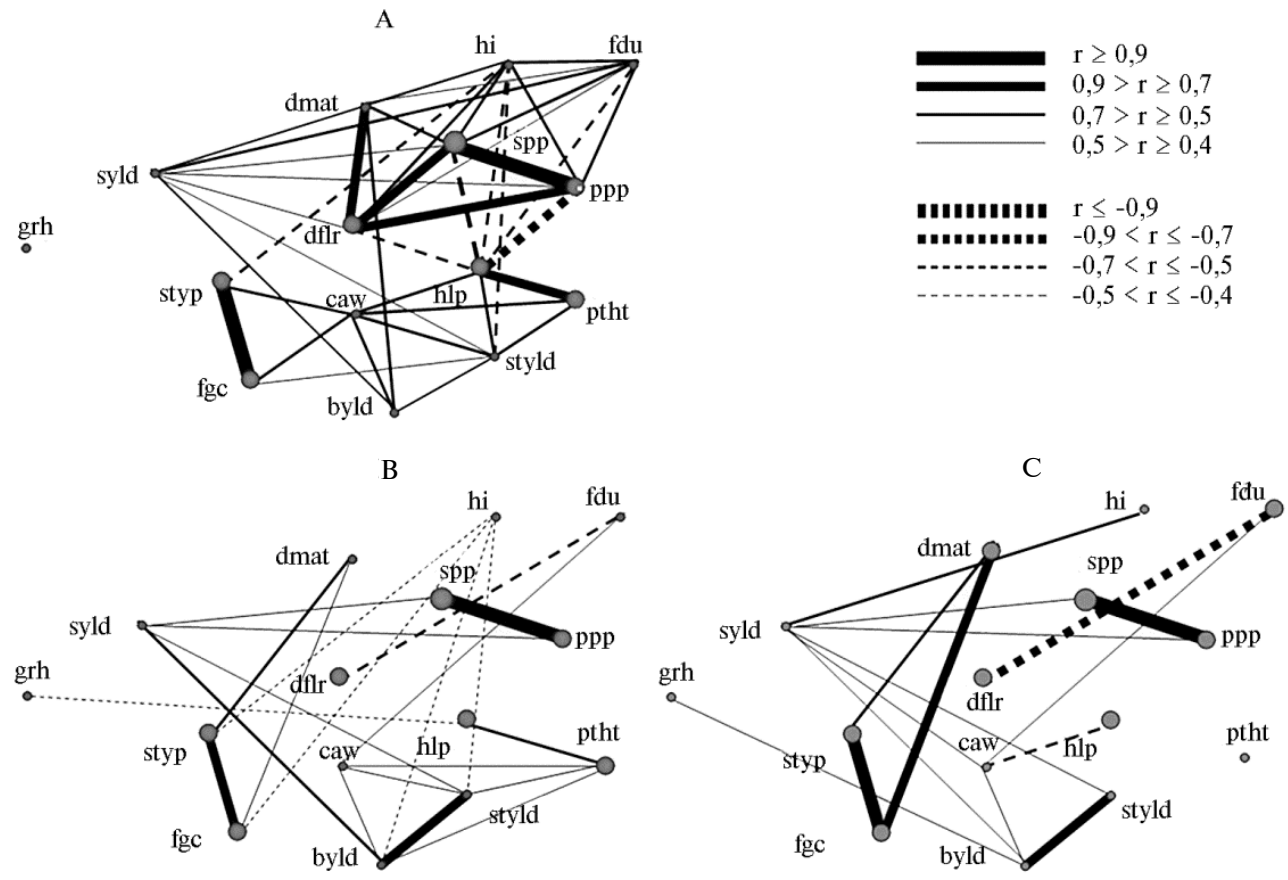

Fig. 3. Correlation structure between the traits of the studied chickpea samples from the VIR collection (N.I. Vavilov All-Russian Institute of Plant Genetic Resources): A - Ethiopian (24 samples), B Turkish (75 samples), C - Turkish (24 samples) (Syria, 2002-2005).

The strongest correlations were found for seed productivity and vegetation period (spp, ppp, dflr, dmat); hi, fdu and syld (harvest index, duration of flowering and seed productivity) were close to these traits. The traits of plant growth character (hlp, ptht, styld) formed the second pleiade, and the separation of these two groups is relatively arbitrary, since they are related by a strong negative correlation through the pod number per plant (ppp). Thus, tall samples with a high pod attachment from Ethiopia differed from the rest because of a small number of pods and seeds and short sprouting-flowering and sprouting-maturing periods. A separate pleiade was formed by the characteristics of the seeds type and the color of flowers (styp, fgc). This pleiade through the width of plant projection (prostration) (caw) was associated with a pleiade of plant growth traits. For example, plants with dark-colored seeds and blue flowers are characterized by a protruding bush shape. An independent trait for the Ethiopian samples was the plant shape type (grh). It should be noted that the harvest index (hi), the duration of the vegetation period (dmat) and a number of other traits were interrelated with different pleiades.

the In the samples from Turkey, due to their greater diversity, the strength of the correlation between the traits was significantly lower (see Fig. 3, B, C). As can be seen from the figures, a decrease in the number of samples in sets affected the strength of the relationship between the traits and had little effect on the correlation structure of pleiades. For most links with correlation coefficients from 0.4 to 0.5 , the $r$ values decreased, which confirmed the well-known rule of decreasing the correlation degree between the traits when the sample size reduced [18]. However, the correlations between some traits have intensified (fgc and dmat, dflr and fdu, hlp and ptht, hlp and grh).

The three correlation pleiades found in all sample sets seem to be more 
characteristic of the species as a whole and are more stable in the cultivated chickpea in general. These are the pleiades of the pod number and seed number per plant (ppp, spp), the color of generative organs (styp, fgc), the plant weight and seed weight per plant (byld, syld). The correlations structure in the Turkish samples, regardless of their size, turned out to be little similar to that of the samples from Ethiopia. It is obvious that in plants growing in different ecological and geographic conditions, specific interrelation systems are formed between the traits, reflecting the presence of different blocks of co-adapted genes and other integrated gene complexes that determine adaptation to a particular environment.

As we noted earlier [11], both the primary and secondary origin centers have a sufficient degree of geographic traits proximity, which fully corresponds to the N.I. Vavilov's theory [19] about the geographical patterns in the distribution of plant genes. In particular, this refers to the fineness and relatively smaller organ size of plants in the eastern (Indian and adjacent) areas and their larger sizes in the Mediterranean.

Chickpea plants from Ethiopia are low; they have small dark seeds of desi type, that is, posses the traits determined by dominant genes. The same regularities were noted by N.I. Vavilov for other crops from this center of origin, including legumes, Lens esculentum Moench, Pisum sativum L. and Lathyrus sativus L. Meanwhile, west of Ethiopia in the Mediterranean region, plants and their seeds become much larger, flowers and seeds are lighter, that N.I. Vavilov explained by "the loss of dominant genes and the accumulation of recessive forms" [19, p. 415].

The relatively narrow limits of the phenotypic traits variation found in the Ethiopian samples, revealed by us, are also confirmed by modern molecular genetic data [20].

Given that $96 \%$ of the Ethiopian samples had the desi seed type, then the Turkish samples had a ratio of the desi and kabul seed type of $43 \%: 57 \%$ and were predominantly light. The maturation period in the Turkish samples was about 7 days longer than in the Ethiopian samples (see Table 2). At the same time, the limits of this trait variability in the Turkish varieties were much wider than those of the Ethiopian samples.

In our previous paper [11], we discussed the reasons for the uniformity of Ethiopian samples and explained this by the country's apparent isolation for a long time, its distance from trade routes and the limited international contacts. Moreover, in Ethiopia, even at the beginning of the twentieth century, agriculture had a primitive character [21]. All Ethiopian samples preserved in the VIR collection (except one) are classified as an Abyssinian ecogeographic group, poorly differentiated and absolutely unique and endemic for Ethiopia [22].

The Turkish group of old local varieties exhibits almost the entire range of traits indicated in the chickpea descriptors, and is characterized by mediumsized vegetative organs, large seeds, and high plant productivity. Modern studies with AFLP-markers (amplified fragment length polymorphism) also show a relatively high variety of Turkish chickpeas [23]. Among the samples collected by P.M. Zhukovsky in Turkey, there were representatives of three ecogeographical groups of varieties: actually Turkish, Spanish and Afghan [24]. That is, by the beginning of the 20th century Turkey had varieties inherent in both the western and eastern Mediterranean, including varieties from areas close to Central and Central Asia, namely, from Iran and Afghanistan. In addition, it was noted that already in those days the crops cultivated in Turkey showed visible traits of ancient breeding [25]. The results of our factorial and discriminant analysis showed an obvious tendency to improve agronomic traits in Turkish local varieties com- 
pared to the more primitive Ethiopian varieties, which raises the question of the possibility to deem the Ethiopian center as more ancient. This issue has already been discussed by VIR botanists [24, 26] and requires a separate review.

So, old local varieties of chickpeas from their origin centers preserved in the VIR collection have traits that reveal their ecological and geographical differentiation, which is in full accordance with the theory of N.I. Vavilov about the geographical patterns in the distribution of plant genes. Morphological, phenological and agronomic traits of chickpea from the primary (Turkey) and secondary (Ethiopia) origin centers reveal a small variety and primitiveness of Ethiopian samples, while the phenotypes from Turkey are characterized by great diversity and possess traces of agronomic improvement. The structure of the trait relationships in the samples from two origin centers is not very similar. It is obvious that in plants growing in different ecological and geographical conditions, specific likage systems between the traits are formed, reflecting the presence of different blocks of co-adapted genes and other integrated gene complexes that determine adaptation to a particular environment. Currently, local varieties of chickpeas from both centers of origin and diversity may be valuable in breeding for early ripeness (Ethiopian samples), high productivity, large seed size, and high plants (Turkish samples).

\section{REFEREN C ES}

1. CGIAR. Chickpea. Available http://www.cgiar.org/our-strategy/crop-factsheets/chick-pea). Accessed May 16, 2017.

2. Wa 11 a c e T.C., M urray R., Z e $1 \mathrm{~m}$ a n K.M. The nutritional value and health benefits of chickpeas and hummus. Nutrients, 2016, 8(12): 766 (doi: 10.3390/nu8120766).

3. Ekspertno-analiticheskii tsentr agrobiznesa «AB-TSentr». Available http://www.ab-centre.ru. Accessed May 16, 2017.

4. Abbo S., B erger J., Turner N.C. Evolution of cultivated chickpea: four bottlenecks limit diversity and constrain adaptation. Functional Plant Biology, 2003, 30: 1081-1087.

5. European landraces on-farm conservation, management and use. Bioversity Technical Bulletin No. 15. M. Veteläinen, V. Negri, N. Maxted (eds.). Bioversity International, Rome, Italy, 2009.

6. Upadhyaya H.D., D wivedi S.L., B a u m M., Varshney R.K., Udupa S.M., Gow a C.L., Hoisingt on D., S ingh S. Genetic structure, diversity, and allelic richness in composite collection and reference set in chickpea (Cicer arietinum L.). BMC Plant Bio$\log u, 2008$ (doi: 10.1186/1471-2229-8-106).

7. va n d e r M a e s e $\mathrm{n}$ L.J.G. Taxonomy, distribution and evolution of chickpea. In: Genetic resources and their exploitation - chickpeas, faba beans and lentils. J.R. Witcombe, W. Erskine (eds.). Hague, Netherlands, 1984.

8. Harla n J.R. Crops and man. American Society of Agronomy-Crop Science Society, Madison, USA, 1992.

9. Vavilov N.I. Tsentry proiskhozhdeniya kul'turnykh rastenii, tom 1 /Pod redaktsiei F.KH. Bakhteeva [Centers of origin of cultivated plants. V. 1. F.Kh. Bakhteev (ed.)]. Leningrad, 1967: 88-202 (in Russ.).

10. Vavilov N.I. Studies on the origin of cultivated plants. Bulletin of Applied Botany, 1926, XVI(2): 1-248.

11. Vishnyakova M.A, B urlyaeva M.O., Bulyntsev S.V., S eferova I.V., P le k $\mathrm{h}$ a $\mathrm{n}$ o v a E.C., $\mathrm{Nu}$ z h d i n S.V. Vavilovskii zhurnal genetiki i selektsii, 2017, 21(2): 170179 (doi 10.18699/VJ16.18-o) (in Russ.).

12. Descriptors for chickpea (Cicer arietinum L.). IBPGR, ICRISAT, ICARDA, Rome, Italy, 1993.

13. Pu ndi r R.P.S., Red d y K.N., M e $\mathrm{ng}$ e s h a V.Y. ICRISAT chickpea germplasm catalog: evaluation and analysis. ICRISAT, Patancheru, India, 1988.

14. Electronic Statistics Textbook. StatSoft Inc, 2013. Available http:// www.stat-soft.com/textbook/. Accessed May 16, 2017.

15. I v a n t e r E.V., K o r o s o v A.V. Vvedenie v kolichestvennuyu biologiyu: uchebnoe posobie dlya studentov biologicheskikh spetsial'nostei [Introduction to quantitative biology]. Petrozavodsk, 2003 (in Russ.).

16. S o k a l R.R., R o h lf F.J. Biometry: the principles and practice of statistics in biological research. NY, USA, 1995.

17. Ro s to va N.S. Trudy Biologicheskogo NII LGU, 1985, 37: 37-54 (in Russ.).

18. L a k i n G.F. Biometriya [Biometry]. Moscow, 1990 (in Russ.).

19. Vavilov N.I. Trudy po prikladnoi botanike, genetike $i$ selektsii, 1927, 17(3): 411-428 (in 
Russ.).

20. Keneni G., Bekele E., Imtiaz M., Dagne K., Getu E., Assefa F. Genetic diversity and population structure of ethiopian chickpea (Cicer arietinum L.) germplasm accessions from different geographical origins as revealed by microsatellite markers. Plant Molecular Biology Reporter, 2012, 30: 654-665.

21. V a vilov N.I. V knige: Izbrannye trudy. Tom 5. Problemy proiskhozhdeniya, geografii, genetiki, selektsii rastenii, rastenievodstva $i$ agronomii /Pod redaktsiei F.Kh. Bakhteeva, S.Yu. Lipshitsa [In: Selected works. V. 5. Plant origin, geography, genetics, breedin, crop production and agronomy. F.Kh. Bakhteev, S.Yu. Lipshits (eds.)]. Leningrad, 1965: 740-751 (in Russ.).

22. P o p o v G.M. V knige: Kul'turnaya flora SSSR. Tom 4. Zernovye bobovye /Pod redaktsiei E.V. Vul'fa [In: Cultivated flora of the USSR. V. 4. Grain legumes. E.V. Vul'f (ed.)]. Leningrad, 1937: 23-71 (in Russ.).

23. Ta le bi R., Naji A.M., Fay as F. Geographical patterns of genetic diversity in cultivated chickpea (Cicer arietinum L.) characterized by amplified fragment length polymorphism. Plant, Soil and Environment, 2008, 54: 447-452.

24. Z hu k ov s k i i P.M. Zemledel'cheskaya Turtsiya (Aziatskaya chast' - Anatoliya) /Pod redaktsiei N.I. Vavilova [Agricultural Turkey. Asian part - Anatolia. N.I. Vavilov (ed.)]. MoscowLeningrad, 1933: 340-346 (Appendix: Chickpea of Anatolia. G.M. Popova, A.M. Pavlova (comps.) (in Russ.).

25. Z h u k ovs k i i P.M. Zemledel'cheskaya Turtsiya (Aziatskaya chast' - Anatoliya) /Pod redaktsiei N.I. Vavilova [Agricultural Turkey. Asian part - Anatolia. N.I. Vavilov (ed.)]. MoscowLeningrad, 1933 (in Russ.).

26. P o p o v M.G. Trudy po prikladnoi botanike, genetike i selektsii, 1928-1929, 21(1): 1-240 (in Russ.). 